\title{
SHELF STABILITY AND ORGANOLEPTIC STUDIES OF SOYMILK MADE WITH ESSENTIAL OIL FROM MENTHA PIPERITA
}

\author{
Chude Charles Onuora \\ Department of Microbiology \\ Chukwuemeka Odumegwu Ojukwu University, \\ Uli, Anambra State, Nigeria
}

\begin{abstract}
The food preservative potential of essential oil (EO) from the aerial parts of cultivated Mentha piperita was determined in soymilk. The plant sample was air-dried and the EO obtained by hydrodistillation. Gas Chromatography-Mass Spectrometry (GC-MS) was used to identify the phyto-components of the fractions and the result revealed a total of $97.36 \%$ portion of the oil which identified menthol $(49.40 \%)$, menthyl acetate $(15.30 \%)$, menthofuran $(11.18 \%)$ and 1,8 -cineole $(6.70 \%)$ as the most abundant. Soymilk was produced and homogenised with the essential oil at varying concentrations of 1:100, 2:100 and 3:100 v/v ratio of essential oil to soymilk. The microbial load of the $M$. piperita treated sample ranged from $1.0 \times 10^{3}$ to $1.1 \times 10^{3} \mathrm{cfu} / \mathrm{mL}$ for bacterial count and $1.0 \times 10^{1}$ to $1.1 \times 10^{1}$ cfu/mL for fungal count. Sensorial scores for color, consistency, mouth feel, taste and overall acceptability was used to compare the treated and untreated soymilk samples for consumer acceptability and the treated product had a mean score of 8.16 for taste which was significantly $(p<$ 0.05) different with the control sample with a mean score of 6.72. The result for overall acceptability showed that M. piperita treated soymilk had good organoleptic properties and was better preferred with mean score of $\mathbf{8 . 1 0}$ when compared to 7.65 mean score of the untreated sample. Hence, the results obtained from this study justify the use of EO from this plant as potent antimicrobial in biopreservation of foods.
\end{abstract}

Keywords - Biopreservation, Shelf-life, Essential oil, Mentha piperita, Consumer acceptance

\section{INTRODUCTION}

The importance of protein in the diet of growing children and its continuous supply is very vital in Africa where the occurrence of protein energy malnutrition (PEM) is a burden. In developing countries and indeed in tropical regions of subSaharan Africa, the production of cow milk and cow milk products is limited, scarce and expensive (Akinyele et al., 1999). Milk is an excellent source of nutrients such as vitamins, amino acid, fats, minerals, proteins and sugar, making it an excellent medium for microbial proliferation (Codex
Alimentarius Commission, 2009). Soya bean seeds contains by weight approximately $32 \%$ carbohydrates, $20 \%$ fat, 5\% minerals, $40 \%$ protein and 5\% vitamins (FAO, 1982); and its lipid content is rich in polyunsaturated fatty acids like linoleic acid (52.3\%) (Lie and Prawirannegatae, 1974).

Soymilk is a blend of soybean and is sometimes referred to as soy drink/ beverage which is a beverage made from soybeans (Glycine max). It is a stable emulsion of oil, water, and protein. Soymilk contains similar proportion of protein as cow milk; with 2 to $3.5 \%$ fat, $2.9 \%$ carbohydrate, and $0.5 \%$ ash content. More so, soymilk consumption has increased due to lipoxygenase-null soybeans and improved processing methods that remove or limit the 'beany' off-flavour of the milk. The health benefit of soya protein to reduce cholesterol (heart disease) has also caused an increase in soymilk sales (and soybean used in foods) as the US FDA now allow a health claim if the food contains at least $6.25 \mathrm{~g}$ of soya protein with low levels of cholesterol, saturated fat, and total fat.

Hence, there is need to produce shelf-stable products as food preservation and safety is a fundamental concern of both consumers and the food industry especially as the number of reported cases of food-associated infections continues to increase. Antimicrobial chemicals had been largely used as foods preservatives, but unfortunately the uncontrolled concentrations to achieve a desired shelf-life increase the risk of toxic residues in the products (Tatsadjieu et al., 2009; Yèhouenou et al., 2010). As a result of the increasing negative effects of these synthetic products on human and animal health, the importance of alternative natural products to control food pathogenic microorganisms is urgently needed (Bankolé, 1997; Burt, 2004; Bajpai et al., 2011).

Essential oils (EOs) as antimicrobial agents are recognized as safe natural substances to their user and for the environment and they have been considered at low risk for resistance development by pathogenic microorganisms (Tatsadjieu et al., 2003; Antunes and Cavaco, 2010). More so, the increasing incidence of cancer related cases and antibiotic resistance which has become one of the most serious global public health 


\section{International Journal of Engineering Applied Sciences and Technology, 2020 Vol. 4, Issue 10, ISSN No. 2455-2143, Pages 272-276 \\ Published Online February 2020 in IJEAST (http://www.ijeast.com)}

threats in this century has resulted in the quest for demand of more organic products. Burt (2004) stated that bacterial susceptibility to EOs appears to increase with a decrease in the $\mathrm{pH}$ of food, because at a low $\mathrm{pH}$, the hydrophobicity of an EO increases, enabling it to more easily dissolve in the lipids of the cell membrane of the target bacteria. There is good evidence to support the use of EO as a food preservative as to limit the use of synthetic substances, hence, the present study aim to evaluate the shelf stability and consumer acceptance of soymilk produced with essential oil extracted by hydrodistillation from Mentha piperita.

\section{MATERIALS AND METHODS}

\section{Pre-extraction Procedures of the Plant Material}

Mentha piperita was purchased; air-dried and was cleaned properly to remove all extraneous materials. Cleaning was done by hands. After drying, the plant was powdered and stored in an airtight polypropylene bag till needed for the extraction.

\section{Extraction of the Plant Material by Clevenger Method}

The aqueous extract from the plant materials was achieved by hydrodistillation using $100 \mathrm{~g}$ of the sample which was added to $800 \mathrm{ml}$ of distilled water in a 2-liter flask. The setup was placed in a balloon heater for 3 hours. At the end of the distillation, two phases were observed, an aqueous phase (aromatic water) and an organic phase (essential oil), less dense than water. The essential oil was collected and stored in sealed amber bottles at $4^{\circ} \mathrm{C}$ to avoid photo-oxidation until used for analysis (Majda et al., 2019).

\section{Characterization of the Extract Using Chromatographic Analyses}

The chemical composition of the aqueous extract was determined by gas chromatography coupled with mass spectrometry (GC/MS) as described by Majda et al., 2019. The GC analysis was performed using a chromatography equipped with a flame ionization detector (FID) and two capillary columns of different polarities OV type: $101(25 \mathrm{~m} \mathrm{x} 0.22 \mathrm{~mm}$ x $0.25 \mathrm{~mm})$ and Carbowax $20 \mathrm{M}(25 \mathrm{~m} \mathrm{x} 0.22 \mathrm{~mm} \times 0.25 \mu \mathrm{m})$. The carrier gas was helium with a flow rate of $0.8 \mathrm{ml} / \mathrm{min}$ and the oven programming temperature between 50 and $200^{\circ} \mathrm{C}$ with a gradient of $5^{\circ} \mathrm{C} / \mathrm{min}$. The Mass spectroscopy (MS) was used in the detection of the constituents and to determine the molecular weight of the compounds and identify the presence of isotopes patterns. MS coupling was performed on a DB1-type fused silica capillary column $(25 \mathrm{~m} \times 0.23 \mathrm{~mm} \times 0.25 \mu \mathrm{m})$ with helium as a carrier gas and temperature programming identical to that of the GC.

\section{Soymilk Production}

To produce soymilk, the soybean was soaked in water for 15 hours and was dehulled with hands. It was then cooked for 25 minutes and wet milled using a household blender. The resultant paste was then mixed with water, poured into a pot and pasteurized on low heat for 5 minutes. It was stirred often so it does not stick to the bottom of the pot. When it was about to boil, the foam was scooped out so it does not over-flow. After boiling, the heat was turned off and left to cool down completely. It was then strained using a cheese cloth to remove the particles. After sieving it was poured into bottles, covered and stored under room temperature for the period of investigation.

\section{Microbial and Shelf Stability Studies}

The soymilk was homogenised with the essential oil at varying concentrations (1:100, 2:100 and 3:100 v/v Essential oil: Soymilk) and was stored at refrigeration temperature for a period of 5 days. The samples were analysed daily, however, this was done in comparison to a control sample which did not contain the EO. The conventional plate count method of APHA (1984) was adopted to determine the total aerobic plate count in the test and control samples. The samples $(\sim 5 \mathrm{ml})$ were taken at daily intervals from the top ( $1 \mathrm{~cm}$ below the surface) and bottom (1 cm above) of the mixture. The harmonized sample $(\sim 1 \mathrm{ml})$ was diluted with saline solution $(9 \mathrm{ml})$ for pour plate count on Nutrient Agar for bacterial count and incubated at $37^{\circ} \mathrm{C}$ for a period of 3 days. Molds were isolated using a selective medium, Potato Dextrose Agar. Colonies of respective microbial types appearing in incubated plates were counted and expressed as colony forming units per gram $(\mathrm{CFU} / \mathrm{mL})$.

\section{Sensory Evaluations}

Sensory evaluation of the soymilk samples was conducted using a 20 member trained panelists drawn from the public. The panelists were given a consent form and were intimated on their duties. The test was conducted while the samples were still fresh and the panelists were required to observe the sample, taste and score. Then rinse their mouth with water before tasting another sample/product. The products were analyzed based on the following parameters of appearance, flavor, mouth feel, consistency and overall acceptability using a nine-point Hedonic scale of $9=$ liked extremely down to I = disliked extremely.

Data Analysis - Data generated were analyzed using one-way analysis of variance and mean separation was done by Duncan's new multiple range test and paired t-tests. Significant difference was accepted at $\mathrm{p}<0.05$.

\section{RESUlT}

\section{Phytochemical Constituents of Mentha piperita}

The extracted essential oil from $M$. piperita was subjected to phytochemical characterizations using GC-MS and the result summarized in Table 1. A total of $97.36 \%$ portion of the oil were identified and menthol (49.40\%), menthyl acetate $(15.30 \%)$, menthofuran $(11.18 \%)$ and 1,8 -cineole $(6.70 \%)$ was observed as the most abundant.

Table 1: Phytochemical screening of $M$. piperita essential oil 
International Journal of Engineering Applied Sciences and Technology, 2020

Vol. 4, Issue 10, ISSN No. 2455-2143, Pages 272-276

Published Online February 2020 in IJEAST (http://www.ijeast.com)

\begin{tabular}{ll}
\hline Percentage & Phyto-composition (\%) \\
\hline$\alpha$-Pinene & 0.28 \\
$\beta$-Pinene & 0.58 \\
$\beta$-Bourbonene & 0.37 \\
$\beta$-Farnesene & 0.30 \\
1,8-Cineol & 6.70 \\
Caryophyllene & 2.83 \\
Germacrene D & 2.94 \\
Menthone & 2.47 \\
Menthofuran & 11.18 \\
Menthol & 49.40 \\
Neomenthol & 2.79 \\
Neomenthyl acetate & 0.65 \\
Menthyl acetate & 15.30 \\
Isomenthyl acetate & 0.60 \\
Sabinene & 0.73 \\
Limonene & 0.24 \\
& \\
Total & $\mathbf{9 7 . 3 6}$ \\
\end{tabular}

\section{Effects of Essential Oil from Mentha piperita on Microbial Population of Soymilk}

The microbial load of the test and control samples was determined and shown in Table 2 and 3. The analysis indicates that the treated and untreated samples had similar microbial load at the start of experiment; hence, the untreated sample observed greater increase in both bacterial and fungal counts as the storage period increases. This may be as a result of the phytochemical constituents contained in the EO of M. piperita.

Table 2: Mean bacterial count of soymilk preserved with essential oil from Mentha piperita

\begin{tabular}{lllllll} 
Conc. $(\mathbf{m L})$ & \multicolumn{5}{c}{ Bacterial Population $(\mathbf{c f u} / \mathbf{m L})$} \\
\cline { 3 - 6 } & 0 day $1^{\text {st }}$ day & $2^{\text {nd }}$ day & $3^{\text {rd }}$ day & $4^{\text {th }}$ day & $5^{\text {th }}$ day \\
\hline $1: 100$ & $<10$ & $1.0 \times 10^{3}$ & $1.0 \times 10^{3}$ & $1.1 \times 10^{3}$ & $1.3 \times 10^{3}$ & $1.4 \times 10^{3}$ \\
2.100 & $<10$ & $1.0 \times 10^{3}$ & $1.0 \times 10^{3}$ & $1.0 \times 10^{3}$ & $1.2 \times 10^{3}$ & $1.2 \times 10^{3}$ \\
$3: 100$ & $<10$ & $<10$ & $<10$ & $1.0 \times 10^{3}$ & $1.0 \times 10^{3}$ & $1.1 \times 10^{3}$ \\
Control & $<10$ & $1.24 \times 10^{3}$ & $1.48 \times 10^{3}$ & $1.53 \times 10^{3}$ & $1.59 \times 10^{3}$ & $1.63 \times 10^{3}$
\end{tabular}

Treatment Ratio - EO: Soymilk

Table 3: Mean fungal count of soymilk preserved with essential oil from Mentha piperita
Conc. $(\mathrm{mL})$

Fungal Population (cfu/mL)

\begin{tabular}{ccccccc} 
& 0 day & $1^{\text {st }}$ day & $2^{\text {nd }}$ day & $3^{\text {rd }}$ day & $4^{\text {th }}$ day & $5^{\text {th }}$ day \\
\hline $1: 100$ & $<10$ & $<30$ & $1.0 \times 10^{1}$ & $1.0 \times 10^{1}$ & $1.1 \times 10^{1}$ & $1.3 \times 10^{1}$ \\
2.100 & $<10$ & $<30$ & $1.0 \times 10^{1}$ & $1.0 \times 10^{1}$ & $1.0 \times 10^{1}$ & $1.1 \times 10^{1}$ \\
$3: 100$ & $<10$ & $<10$ & $1.0 \times 10^{1}$ & $1.0 \times 10^{1}$ & $1.0 \times 10^{1}$ & $1.1 \times 10^{1}$ \\
Control & $<10$ & $1.0 \times 10^{1}$ & $1.4 \times 10^{1}$ & $1.4 \times 10^{1}$ & $1.7 \times 10^{1}$ & $2.2 \times 10^{1}$ \\
\hline
\end{tabular}

Treatment Ratio - EO: Soymilk

\section{Effects of Essential Oil from Mentha piperita on Sensory Attributes of Soymilk}

The essential oil from M. piperita was used to produce soymilk and the sensory attributes were analyzed to determine its suitability for consumption and acceptability. However, the results showed no significant $(\mathrm{p}<0.05)$ difference from the results obtained for the control sample (Figure 2) and met the requirement of the Nigerian Industrial Standards (NIS 550:2007 Standard for Soya Milk).

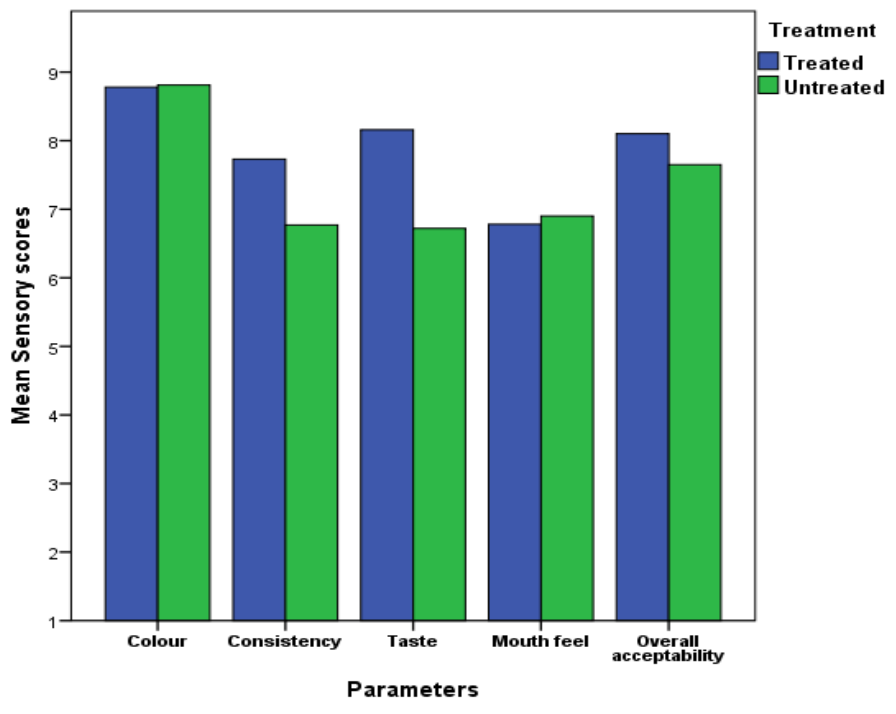

Figure 1: Sensory scores of soymilk made with EO from M. piperita and control

\section{DISCUSSION}

The phytochemical constituents of M. piperita oil suggest it could be a good source of some nutritional /medicinal valuable elemental component such as iron, magnesium, potassium, sodium and calcium but no composition of deleterious element such as lead or arsenic was observed. The data obtained for bacterial and fungal counts of the keeping quality showed that the inhibitory effect was dose dependent and this is in 


\section{International Journal of Engineering Applied Sciences and Technology, 2020 Vol. 4, Issue 10, ISSN No. 2455-2143, Pages 272-276 \\ Published Online February 2020 in IJEAST (http://www.ijeast.com)}

agreement with findings of Bakkali et al. (2009) who also observed a dose dependent effect of Garcina kola seed oil.

The microbial study for effect of $M$. piperita on the keeping quality of the soymilk sample during five days of experiment observed a decrease in both bacterial and fungal growth as the concentration increases. However, both the treated and untreated samples showed very low microbial counts at the start of the experiment and was subjected to the same storage temperature, the decreased counts observed in the treated sample was attributed to the antimicrobial potential of the EO from $M$. piperita. Application of essential oils of plant-origin antimicrobials such as leaves of Ocimum gratissimum, Zingiber officinale, Syzygium aromaticum, Pimenta racemosa, Cinnamomum zeylanicum, Xylopia aethiopica and Cymbopogon citratus could be a potential alternative to synthetic preservatives for reasons that they have large spectrum activity against Gram negative bacteria, Gram positive bacteria and fungi which are known to be the main factor of food deterioration (Harrigan et al., 1994; Ajiwe et al., 1998; Tatsadjieu et al., 2003; Asekun and Adeniyi 2004; Konnings et al., 2004).

Sensorial scores for color, consistency, mouth feel, taste and overall acceptability show that soymilk made with EO from $M$. piperita could compete favorable with known desirable attributes of soymilk. The result for color showed that the $M$. piperita treated soymilk had a mean score of 8.78 which was extremely liked. Color is considered an important property of food product and could affect consumer acceptance of the product. The treated product also had a mean score of 8.16 for taste and was significantly $(\mathrm{p}<0.05)$ different with the control sample. Mouth feel was used as an indication of texture for the soymilk samples and characterized by degree of hardness or softness of the product. To compare for mouth-feel, the treated soymilk as well as the control sample was produced with same measurement of soybean, water and other components; the only variance was the addition of $M$. piperita in the treated sample. The sensorial data obtained for mouth feel showed a mean score of 6.78 for the treated sample and had no significant $(\mathrm{p}>$ 0.05) difference with the untreated soymilk sample. Hence, mouth feel is an important parameter to consider in developing new beverage products, as this will influence consumer perception and acceptability.

\section{CONCLUSION}

Essential oils are complex mixtures that can contain approximately 20 to 80 individual constituents (ICs) at different concentrations. The chief group of ICs forming the EOs results from the union of terpenes and terpenoids, and the other group contains aromatic and aliphatic constituents. Hence, most EOs and their ICs are cited as "generally recognized as safe" (GRAS) by the US FDA and are registered by the European Commission for use as flavoring substances in foods; and also considered to have no significant or marginal toxic effects regarding the possible amount of use in food. However, some researchers have stated that high concentrations of EOs which are necessary to achieve the desired antimicrobial effects may likely impact undesirable sensory characteristics on the food. However, the concentration used in the present study observed better sensory attributes in the soymilk as shown in the mean sensory data for taste. Finding new options of EOs which could be used in food and drink production from locally available plant materials will not only improve health but ensure food security and impart on local economy.

\section{REFERENCE}

[1] Ajiwe, E.I.V., Okeke, A.C., Ogbuagu, O.J., Ojukwu, U. and Onwukeme, I.V. (1998). Characterization and applications of oils extracted from Canerium schweinfurttii, Vitex doniana and Xylopia aethiopica fruits/seeds. Bioresource Technology 64: $249-252$.

[2] Akinyele, S.J., Fawole, M.O. and Akinyosoye, E.A. (1999). Microorganisms associated with fresh cow milk "wara" and "nono", two local milk products by Fulani woman in IIorin, Kwara state, Nigeria. Nigerian Food Journal 17: 10 - 15.

[3] American Public Health Association (1984). Compendium of Methods for the Microbiological Examination of Foods, 2nd edition. APHA, Washington, DC. pp. $1775-1778$.

[4] Antunes, M.D.C. and Cavaco, A.M. (2010). The use of essential oils for postharvest decay control. A review. Flavour and Fragrance Journal 25(5): 351 - 366.

[5] Asekun, O.T. and Adeniyi, B.A. (2004). Antimicrobial and cytotoxic activities of the fruit essential oil of Xylopia aethiopica from Nigeria. Fitoterapia 75(3-4): 368 - 370.

[6] Bajpai, V.K., Baek, K.H. and Kang, S.C. (2011). Control of Salmonella in foods by using essential oils: A review. Food Research International 23 (2): 157 - 165.

[7] Bakkali, F., Aver beck, S., Aver beck, D. and Idaomar, M. (2008). Biological effects of essential oils: A review. Food and Chemical Toxicology 46: 446-475.

[8] Bankolé, S.A. (1997). Effect of essential oil from Nigerian medicinal plants (Azadirachta indica and Mrinda lucida) on growth and aflatoxin B1 production in maize grin by toxigenic Aspergillus flavus. Letters in Applied Microbiology 24: 190192.

[9] Burt, S. (2004). Essential oils: their antibacterial properties and potential applications in foods - a review. International Journal of Food Microbiology 94 (3): 223-53. 
[10] Codex Alimentarius Commission (2009). Basic Texts Food Hygiene. $4^{\text {th }}$ Ed. Secretariat of the Joint FAO/WHO Food Standards Programme, Rome, FAO, p 477.

[11] FAO (1982). Legumes in human nutrition. FAO Food and Nutrition Paper No. 20. Food and Agriculture Organization, Rome, p 237.

[12] Harrigan, G.G., Bolzani, V.S., Gunatilaka, L.A.A. and Kingston, I.G.D. (1994). Kaurane and trachylobane diterpenes from Xylopia aethiopica. Phytochemistry 36 (1): 109 - 113.

[13] Konnings, G.H., Agyare, C. and Ennison, B. (2004). Antimicrobial activity of some medicinal plants from Ghana. Fitoterapia 75 (1): 65 - 67.

[14] Lie, G.H. and Prawirannegatea, D. (1974). Nutritive value of various legumes used in the Indonesian diet presented at first Asian workshop on grain legumes, Bogor, Indonesia. pp. 213 259.

[15] Majda, E., Bouchra, L., Imane, N., Taha, E., Abdelhak, B., Mustapha, T., Mahdi, C. and Noureddine, E. (2019). Extraction of Essential Oils of Rosmarinus officinalis L. by Two Different Methods: Hydrodistillation and Microwave Assisted Hydrodistillation. The Scientific World Journal Article ID 3659432. 1 - 6 .

[16] Tatsadjieu, L.N., Essia-Ngang, J.J., Ngassoum, M.B. and Etoa, F.X. (2003). Antibacterial and antifungal activity of Xylopia aethiopica, Monodora myristica, Zanthxylum xanthoxyloides and Zanthoxylum leprieurii from Cameroon. Fitoterapia 74 (5): 469-472.

[17] Tatsadjieu, L.N., Dongmo, P.M., Ngassoum, M.B., Etoa, F.X. and Mbofung, C.M.F. (2009). Investigations on the essential oil of Lippia rugosa from Cameroun for its potential use as antifungal agent against Aspergillus flavus. Food Control 20: 161 - 166.

[18] Yèhouenou, B., Wotto, V., Bankolé, L., Sessou, P., Noudogbèssi, J.P. and Sohounhloué, D. (2010). Chemical study and antimicrobial activities of volatile extracts from fresh leaves of Crassocephalum rubens (Juss \& Jack) against foodborne pathogens. Scientific Study Research 11 (3): 343 - 351. 